\title{
Development Strategies of Oelsonbai Research Center Scientific Tourism in KHDTK Oelsonbai Kupang
}

\author{
Wieke Herningtyas $^{1 *}$, Gerson Ndawa Njurumana ${ }^{1}$, Maria Elisabet Saptaria Feriani ${ }^{2}$, Is Mugiono ${ }^{3}$ \\ ${ }^{1}$ Environment and Forestry Research and Development Institute of Kupang. Jl. Alfons Nisnoni No.7, Kupang, 85115, Nusa \\ Tenggara Timur, Indonesia \\ 2 Environment and Forestry Research and Development Institute of Pekanbaru. Jl. Hr. Soebrantas Km 8, Pekanbaru, 28294, Riau, \\ Indonesia \\ ${ }^{3}$ Center of Environment and Forestry Human Resources Education and Training. Jl. Mayjen Ishak Djuarsa, Bogor, 16118, Jawa \\ Barat, Indonesia \\ * Corresponding Author. E-mail address: wiekehtyas@gmail.com
}

ARTICLE HISTORY:

Received: 25 September 2021 Peer review completed: 29 November 2021 Received in revised form: 13 December 2021 Accepted: 6 January 2022

\section{KEYWORDS:}

Natural tourism

Oelsonbai Research Center

Scientific tourism

SWOT Analysis

Tourism

(C) 2022 The Author(s). Published by Department of Forestry, Faculty of Agriculture, University of Lampung in collaboration with Indonesia Network for Agroforestry Education (INAFE) This is an open access article under the CC BY-NC license:

https://creativecommons.org/licenses/by$\mathrm{nc} / 4.0 \%$.

\begin{abstract}
Oelsonbai Research Center is one of the management instruments of Forest Area for Specific Purposes (Kawasan Hutan Dengan Tujuan Khusus) Oelsonbai to help promote research and development results bundled in scientific tourism package. The Oelsonbai Research Center development was still new, so this research aimed to determine development strategies of the Oelsonbai Research Center scientific tourism in forest area for specific purposes Oelsonbai. This research was conducted from June to July 2021. The research methods used were interviews using questionnaires on 33 respondents, field observation, in-depth interviews with the administrators, and Strength, Weakness, Opportunities, Threats (SWOT) analysis. The results indicated that Oelsonbai Research Center could develop into a tourism area. Therefore, strategies to develop the Oelsonbai Research Center are proposed in this research. The proposed strategies are: developing the potential of the area with better quality tourism objects, executing the created forest area and scientific tourism attraction planning, increasing socialization and promotion activities with digital media, increasing collaborative relations between researchers and other researchers and academics in education, research and scientific tourism, involving the community in tourism activities by establishing business institutions such as cooperatives and establishing cooperation with other parties in developing the Oelsonbai Research Center scientific tourism.
\end{abstract}

\section{Introduction}

Forest Area for Specific Purposes or Kawasan Hutan Dengan Tujuan Khusus (KHDTK) is a forest area used for specific purposes such as research, development, education, training, religion, and culture determined by the government. Therefore, the customary people, educational institutions, research institutions, social and religious institutions can manage it (Nugroho et al. 2017). According to the Law of the Republic of Indonesia Number 41 of 1999 regarding Forestry, KHDTK is required for public interest like research and development, education and training, and religion and culture by not changing the primary function of the forest area. In 2019, there were 35 KHDTK scattered all over Indonesia and 13 of those were organized by the working unit of 
Research, Development, and Innovation Agency or Badan Litbang dan Inovasi (BLI), Ministry of Environment and Forestry, and have an area of 37,569.05 ha. The purposes of KHDTK on the working unit of BLI are for basic and applied researches and the application and development of technology transfer (MoEF RI 2020). KHDTK has strategic value due to its essential role as a learning facility for forestry research and innovation activities used by the government as a research-based reference for decision making (Maskulino and Panjaitan 2020; Nugroho et al. 2017).

KHDTK Oelsonbai is one of facilities managed by Environment and Forestry Research and Development Institute of Kupang or Balai Penelitian dan Pengembangan Lingkungan Hidup dan Kehutanan Kupang (BPPLHK Kupang). KHDTK Oelsonbai was officially declared as KHDTK according to the Decision Letter of Minister of Forestry Number 11 of 2020, covering an area of 21.82 ha. KHDTK Oelsonbai has been managed since 1987 as a research forest situated in Fatukoa Sub-District, Maulafa District, Kupang City, Nusa Tenggara Timur Province. In the KHDTK area, there are protected wildlife populations (Rafii et al. 2020) and KHDTK Oelsonbai. KHDTK Oelsonbai has a role as a biodiversity habitat, which is shown by the existence of endemic flora and fauna of Nusa Tenggara Timur such as teak (Tectona grandis), acacia (Acacia mangium), sandalwood (Santalum album), faloak (Sterculia quadrifida), Javan deer (Rusa timorensis), eclectus parrot (Eclectus roratus), and Rote snake-necked turtle (Chelodina mccordi) (BPPLHK Kupang 2020). In addition, a study by Hidayat (2016) identified 33 bird species within the forest area.

KHDTK not only functions to support research, development, and innovation activities; but also to spread the result of research, development, and innovation. The great potential that exists in KHDTK includes nature tourism, environmental services, agroforestry, ecotourism, or environmental education tourism (Bangsawan et al. 2021; Barus et al. 2018). Other uses of KHDTK are for nature tourism activities, including recreation, camping, mountain biking, outbound, tracking (forest exploration), observation of flora and fauna, environmental education tours, and many other activities (Rafii et al. 2020). BPPLHK Kupang makes KHDTK Oelsonbai a tourism destination due to its strategic location and easy accessibility. According to Hutapea et al. (2021), KHDTK, which is easy to visit, can strategically be a tourist destination. Therefore, KHDTK Oelsonbai can be an alternative tourist destination in Kupang City.

Following the Long-Term Management Plan or Rencana Pengelolaan Jangka Panjang (RPJP) of KHDTK Oelsonbai in 2020-2039, KHDTK Oelsonbai is planned to be a model and reference of the excellent semi-arid ecosystem by implementing research and development results inclusively, innovatively, and competitively. To support it, one of the missions is to manage reserved forests using a scientific tourism concept known as Oelsonbai Research Center. Development of scientific tourism in KHDTK has also been carried out, such as scientific tourism developed by BPPLHK Aek Nauli at KHDTK Aek Nauli since 2018 (Maskulino and Panjaitan 2020; Subarudi et al. 2020). According to Saputra and Setiawan (2014), all existing potentials, both in the form of environmental products and services, must be explored as widely as possible in a wise and planned manner to provide benefits to humans and development. The rising public interest in enjoying the beauty and attraction of wildlife has encouraged the development of captive breeding for tourism purposes (Hutapea et al. 2021). Tourism objects can also be used as a learning resource and provide a direct learning experience (Aswita et al. 2020; Bos et al. 2015). 
The Oelsonbai Research Center scientific tourism in KHDTK Oelsonbai aims to prioritize research results of Endemic flora and fauna in the semi-arid ecosystem area of Nusa Tenggara Timur, which have been used as branding by BPPLHK Kupang working unit (BPPLHK Kupang 2020). As we know, Nusa Tenggara Timur is a semi-arid region (Messakh et al. 2017), which is also part of Wallacea, which has a high level of endemicity (Yuni and Yuda 2020). Therefore, this attraction consists of three main aspects, namely: 1) wild animal tourism attraction used to attract visitors from education and public clusters and to function as a natural laboratory, 2) combination of tourism and dissemination of BPPLHK Kupang excellent product, so it can be spread and used by stakeholders, 3) as a research site to support data exploration, field practices, research, and development (BPPLHK Kupang 2020).

The Oelsonbai Research Center scientific tourism is expected to be part of efforts in optimizing KHDTK Oelsonbai potentials through its usage not only to support research and development activities for the researchers but also to support educational purposes such as natural ecosystems, diversification, and conservation (Bhuiyan et al. 2010; Rahmawati et al. 2020) and scientific tourism activities (Maskulino and Panjaitan 2020; Subarudi et al. 2020). Research and development activities are conducted in KHDTK Oelsonbai. At the same time, Oelsonbai Research Center scientific tourism is an essential part of KHDTK aimed to promote research and development results in tourist attraction as an educational process. This education is expected to be an interesting activity for visitors. Tourist sites as learning sources can realize carious information, knowledge, experience, and skill during the teaching and learning process (Aswita et al. 2020; Bhuiyan et al. 2010; Rahayu et al. 2015; Setiyono et al. 2012). They are allowed to learn and use research, development, and innovation results generated by the researchers. Through acting, fun learning, and the emotional experience of visitors influenced destination image (Li et al. 2021).

Since this scientific tourism is still new, the administrators need to plan development strategies of the Oelsonbai Research Center scientific tourism intended to meet visitor needs. Visitor evaluation is very important since visitors are the users of the Oelsonbai Research Center scientific tourism. According to Konu et al. (2015), the role of the customer has been highlighted in the product and service development process. The importance of customer involvement is seen as an effective strategy to increase success service (Sjodin and Kritensson 2021), including on the Oelsonbai Research Center scientific tourism. This research aims to determine the development strategies of Oelsonbai Research Center scientific tourism in KHDTK Oelsonbai.

\section{Materials and Methods}

This research was conducted at KHDTK Oelsonbai from June to July 2021. Tools and equipment used were stationery, camera, and questionnaires. This research used methods of qualitative descriptive and quantitative descriptive. Data collecting to identify visitor evaluation toward KHDTK Oelsonbai was done by interviewing 33 respondents who have visited KHDTK Oelsonbai using google forms questionnaires. The number of samples was more than 30 as a minimum requirement for normal distribution. Alwi (2015) stated that the average statistic has normal distribution for infinite samples size, but in practice, it can be applied to a minimum sample size of 30. The sample size was also considered representative of the number of visitors in the last six months. The number of visits recorded in January-June 2021 was 74 visits. According to Gay et al. (2012), the minimum sample size is $10 \%$ of the population for descriptive research. The 
sampling of respondents was done by purposive sampling. Sampling was done indirectly through google form questionnaires because there were no visitors during the COVID-19 pandemic. Google form questionnaires were distributed through contacts obtained from the guestbook of KHDTK Oelsonbai. The data was also gathered through field observation and in-depth interviews with KHDTK Oelsonbai administrators to identify characteristics of KHDTK Oelsonbai management and its problems which would lead to determining strategies in SWOT analysis. Information regarding visitor evaluation toward KHDTK Oelsonbai was done to identify visitor perception of tourism services through 25 questions that respondents must answer. Visitors' evaluations observed in this research were nature beauty, accessibility, level of cleanliness, promotional media, facilities and infrastructures, transportation, local hospitality, staff tourism object interpretation skills, society involvement, and level of comfort.

The evaluation of the natural tourism attraction was identified through Guidelines for Operational Region and Natural Tourism Attraction or Pedoman Analisis Daerah Operasi Obyek dan Daya Tarik Wisata Alam (ADO ODTWA) (MoF RI 2003). ADO ODTWA is a standard for assessing the potential and attractiveness of natural tourism objects (Sihite et al. 2018). The criteria which had to be met were: tourism attraction, accessibility, the social-economic environment condition, accommodations, supporting facilities and infrastructures, and clean water availability. Every evaluation had been measured according to each criterion using the following equation:

$$
S=N \times B
$$

where $S$ is the score of a criterion, $N$ is the amount of every criterion's element value, and $B$ is the quality of value measured for each element.

The score measured was then compared with the total score of a criterion. According to Karsudi et al. (2010), the percentage of the qualification/eligibility can be justified after the comparison. The index of a tourist attraction can be determined by:

- Properness level $>66.6 \%$ means the tourist attraction can be developed further

- Properness level 33.33\% - 66.6\% means the tourist attraction does not meet the criteria to be developed further

- Properness level $<33.3 \%$ means the tourist attraction is not eligible to be developed any further

To develop Oelsonbai Research Center scientific tourism strategies in KHDTK Oelsonbai using SWOT (Strengths, Weaknesses, Opportunities, and Threats) analysis, the data gathered from 33 visitors in google form questionnaires field observation, and in-depth interviews with the administrators. A SWOT analysis is based on two tiers of analysis which are conducted separately: the first step is to analyze internal factors (local analysis), which contain a discussion on strengths and weaknesses according to the aims of the SWOT, second step is to analyze external factors (global analysis) which contain a discussion on relevant opportunities and threats (Reihanian et al. 2012). According to Reihanian et al. (2012), SWOT analysis steps were:

1. The internal factors were classified as Strengths (S) or Weaknesses (W), and those external factors were classified as Opportunities (O) or Threats (T). accordingly, a list of Strengths summarizes (Ss), Weaknesses summarize (Ws), Opportunities summarize (Os), and Threats summarize (Ts) were drawn.

2. These factors were then weighted and rated by a panel of experts, and the final score was calculated. For qualification of weighed on each variable, each factor was rated from 4 (high importance), 3 (important), 2 (unnecessary), 1 (very unnecessary), based on the contribution of 
influence of these strengths or weaknesses on the achievement of the Oelsonbai Research Center scientific tourism development. The greater the weight, the higher the contribution/influence to the achievement of the Oelsonbai Research Center scientific tourism development will be. The weight of all strategic factors must be 1 . To calculate the ratings, each factor was scaled from 4 (very good), 3 (good), 2 (not good), 1 (very not good) based on the position of each factor with the amount of capital owned by KHDTK Oelsonbai.

3. To determine each factor's final score, the weight was multiplied by ratings.

4. Once each factor's total score was calculated, they were summed to calculate the final score.

The SWOT matrix from the preparation of external and internal strategies and the SWOT analysis emerged 4 (four) strategies: SO, ST, WO, and WT. Then, the set of priorities strategy by adding up the weighting code values of each strategy determined in the SWOT matrix so that the largest total score was obtained which made the highest priority (Meizannur and Wulandari 2015).

\section{Results and Discussion}

\subsection{Visitor Evaluation Toward KHDTK Oelsonbai}

The Oelsonbai Research Center scientific tourism at KHDTK Oelsonbai was developed in early 2020. Until this research was conducted, there had been no visits from public tourists due to the COVID-19 pandemic. Visitors were dominated by researchers from BPPLHK Kupang and other agencies interested in conducting research. There were also several other visits, such as students' field practice from several universities in East Nusa Tenggara. The COVID-19 pandemic is thought to have influenced the limited number of visits. Pandemic has had significant repercussions for tourism in natural areas globally (Newsome 2020) and Indonesia (Cahyadi and Newsome 2021). So, samples were taken using google form questionnaires with the target people who had visited KHDTK Oelsonbai.

The respondents' characteristics are presented in Fig. 1 to Fig. 3, and the visitor evaluation result is shown in Fig. 4.

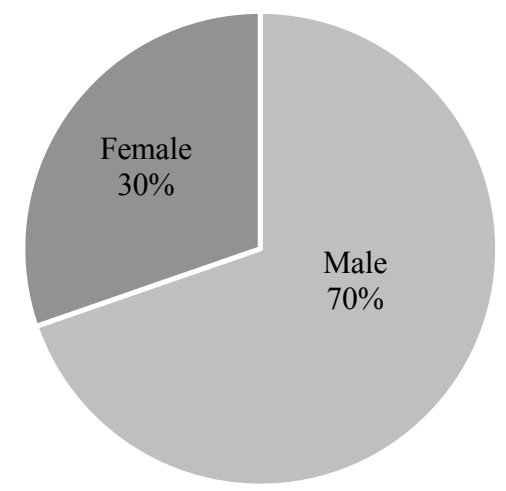

Fig. 1. Identification of respondents by gender.

Fig. 1 shows that most respondents are male (70\%). It might be because not everyone who got google form questionnaires via WhatsApp messenger responded and filled out. Participation of females in filling out online questionnaires was low compared to males. Most females did not answer and ignored messages sent by researchers, while males were responsive by answering messages and filling out questionnaires. This is in accordance with the research results of Fitroh et al. (2019), stating that males tend to have a higher willingness to help others than females. Also, 
respondents in this study were voluntary or without incentives. The number of responses in online questionnaires without incentive is lower than with incentives (Silvano et al. 2020).

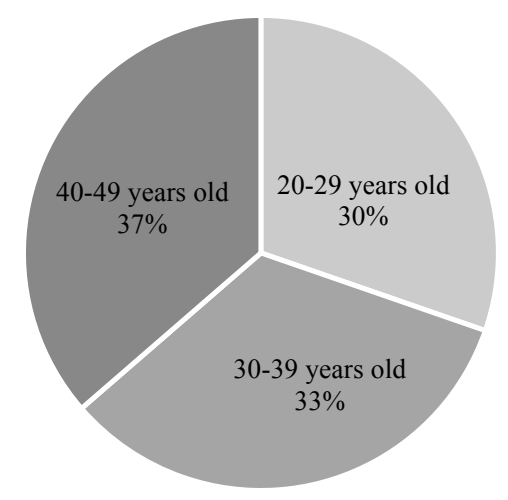

Fig. 2. Distribution of respondents by age.

The age of respondents is a factor that was considered in the selection of respondents. In this study, visitors who became respondents must be over 17 years old. It is because, at that age, they are considered to have understood the situation and conditions at KHDTK Oelsonbai. Although not all of the online questionnaires distributed were filled out, it was found that the number of respondents in all age groups was almost the same (Fig. 2). Silvano et al. (2020) stated that giving incentives or without incentives on online questionnaires has no significant effect on the age groups. In addition, in today's digital era, almost all ages are technology literate. Based on MCI RI (2017), more than half of Indonesian people already own a smartphone, with a percentage of more than $50 \%$ of users in each age group.

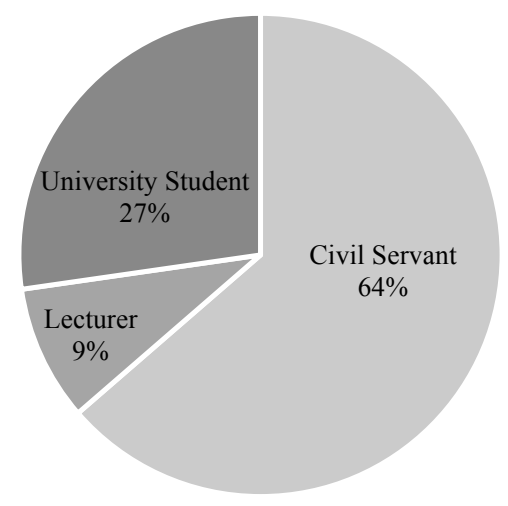

Fig. 3. Identification of respondents by occupation.

Respondents with jobs as civil servants had the highest number of 21 respondents, or $64 \%$. These civil servants consist of researchers and other employees who conducted research or visited KHDTK Oelsonbai. There were 9 respondents with jobs as university students and respondents with jobs as lecturers with 3 respondents or 9\%. From online questionnaires that had been distributed, most of those filled out were already working, while university students' responses were very poor and tended to ignore. People who are well educated and have more knowledge will communicate well (Dewi et al. 2021). All respondents in this study had a minimum of high school education and considered a critical mindset. According to Chen et al. (2021), with an increase in education, tourist perceptions, expectations, attitudes, and the value orientation of tourism is 
constantly changing, and their demand from tourism is also increasing. Hence, they were expected to provide detailed and accurate information in answered google form questionnaires.

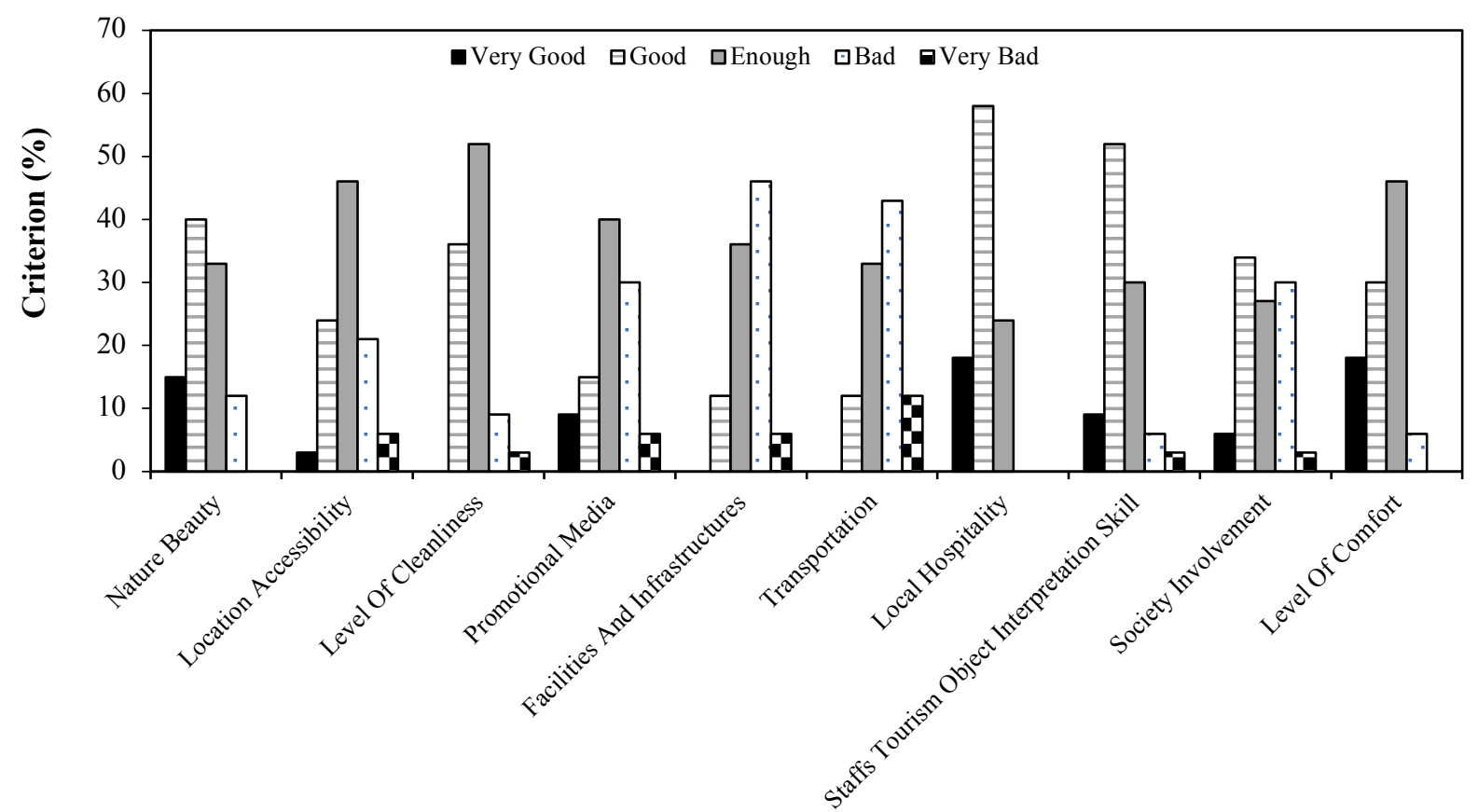

Fig. 4. Visitor evaluation toward KHDTK Oelsonbai.

In order to promote tourism, it is very important to understand the value orientation, satisfaction, and future development demands, which can guide the future (Chen et al. 2021). Hence, visitors' experience is fundamental for destination image and development (Jangra et al. 2021). Based on the visitor evaluation of KHDTK Oelsonbai shown in Fig. 4 above, it can be inferred that KHDTK Oelsonbai has not been managed optimally. In order to get positive feedback from the visitors, it is necessary to improve the management, especially in terms of location accessibility, level of cleanliness, information from the media, facilities, and infrastructure, transportation and visitor comfort levels. The location can be accessed using the main asphalt road, but the road inside the macadam road (dirt road) area needs maintenance. Cleanliness is sufficient because field officers regularly clean it and the trash cans are available in front of the building but look untidy due to less arrangement. Information of KHDTK Oelsonbai can be obtained through the internet, but it is still limited through newspapers/magazines and television and most visitors claim to have received information from friends/relatives and others in the form of information from the campus/office. There is still a lack of facilities and infrastructure because there is no shelter or resting place while enjoying the view, gazebos, and Instagram-able photo spots to attract visitors. There is no public transportation available that goes directly to KHDTK Oelsonbai. Despite the limited facilities and infrastructure, visitors still feel enough convenience.

Based on the questionnaire which describes the aspects of critics and suggestions as well as visitors' expectations for KHDTK Oelsonbai management presented in Fig. 5, it is necessary to improve and add facilities and infrastructure, add supporting facilities (with complete information boards, signposts, seats, and trash cans), increase promotion, add types or variants of tourism attractions to attract more visitors and provide scientific atmosphere, maintain road infrastructure in the KHDTK Oelsonbai area, and to improve staff performance and service, improve area planning and cleanliness, especially toilets cleanliness and the need for partnership or management 
cooperation with third parties to be better managed with a better source of funds than relying solely on DIPA funds from BPPLHK Kupang. These can help management to better understand their visitors' needs (Pezenka and Wiesmayer 2020). Furthermore, management must decide which aspects should receive the most attention and how investors can best be directed to satisfy visitors (Pezenka and Wiesmayer 2020). In this case, facilities and infrastructure are aspects that need attention from management, as shown in Fig. 4 and Fig. 5.

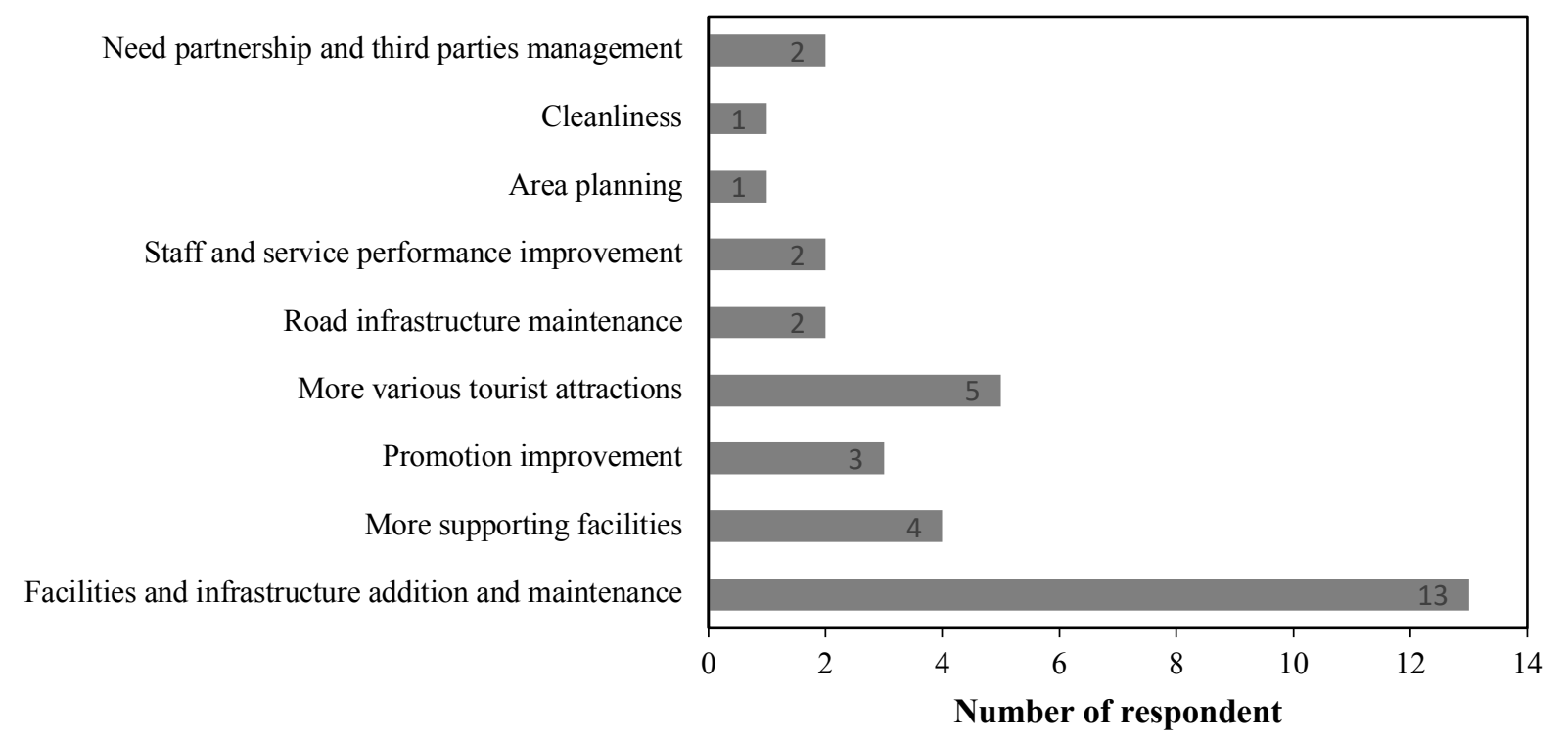

Fig. 5. Summary of KHDTK Oelsonbai visitors' critics, suggestions, and expectations

\subsection{Tourism Attraction of KHDTK Oelsonbai}

According to Affandy et al. (2016), one of the non-timber products with potential and advantages is potential objects and tourism attractions. The factor which supports the potential of the KHDTK Oelsonbai area to be scientific tourism is its natural tourism potential. Sumarsono et al. (2020) stated that in the context of developing tourism, it must be directed at the utilization of natural resources. Therefore, the object of tourism attraction in this study used the object of natural tourism attraction. The tourism attraction evaluation results of KHDTK Oelsonbai in accordance with ADO ODTWA (MoF 2003) are presented in Table 1.

The object of tourist attraction is the first consideration in doing tourism. The attraction was assessed based on the prominent uniqueness of natural resources, sensitivity to natural resources, air and location cleanliness, security, comfort, and variety of activities. Each of these elements may attract more tourists to visit. Based on evaluation results of the ADO ODTWA criteria, KHDTK Oelsonbai had an index of properness potential value of $82.81 \%$, which indicated its potential and properness to be developed into a tourism area. According to Karsudi et al. (2010), the area can be developed as a tourism area if the properness potential value is above $66.6 \%$. Some of the evaluation criteria used showed that the potential value index of tourist attractions is not quite high. Further attention and improvement are required to overcome this (Purwanto et al. 2014; Susana et al. 2020). The tourism object attraction in KHDTK Oelsonbai can be strong enough to attract more visitors. Popularity and ratings are factors that increase the number of visitors (Hernandez et al. 2021). Furthermore, making the Oelsonbai Research Center scientific tourism 
popular on social media is important. Social media shape tourist photography and tourist gaze at the destination (Dinhopl and Gretzel 2016).

Table 1. KHDTK Oelsonbai tourism attraction evaluation

\begin{tabular}{llcccccc}
\hline No & Evaluation Element & Weight & Value & Score & $\begin{array}{c}\text { Maximum } \\
\text { Score }\end{array}$ & $\begin{array}{c}\text { Potential } \\
\text { Value Index } \\
\mathbf{( \% )}\end{array}$ & Note \\
\hline 1. & Tourism attraction & 6 & 170 & 1,020 & 1,260 & 80.95 & proper \\
2. & $\begin{array}{l}\text { Accessibility } \\
\text { 3. }\end{array}$ & 5 & 90 & 450 & 600 & 75.00 & proper \\
& $\begin{array}{l}\text { Condition of the social- } \\
\text { economic environment }\end{array}$ & 5 & 90 & 450 & 600 & 75.00 & proper \\
4. & $\begin{array}{l}\text { Accommodation } \\
\text { 5. }\end{array}$ & 3 & 60 & 180 & 180 & 100.00 & proper \\
$\quad \begin{array}{l}\text { Supporting facilities } \\
\text { and infrastructures }\end{array}$ & 3 & 100 & 300 & 300 & 100.00 & proper \\
$\begin{array}{l}\text { Clean water } \\
\text { availability }\end{array}$ & 6 & 130 & 780 & 900 & 86.67 & proper \\
\hline & & & & & & \\
\hline
\end{tabular}

In order to develop tourism attraction objects as ODTWA, promoting and marketing efforts are required to attract market potential, improve management and services according to the standards, fulfill the required accommodation and increase the diversification of tourism attractions (Karsudi et al. 2010). BPPLHK Kupang has already planned to develop tourism attractions as stated in the RPJP (BPPLHK Kupang 2020), several plans for the theme of tourism attractions which are offered by the Oelsonbai Research Center scientific tourism at KHDTK Oelsonbai, area 1) exploring the sandalwood (Santalum album) life, 2) admiring Rote snakenecked turtle (Chelodina mccordi), one of the endemic animals of Nusa Tenggara Timur, 3) spending time with the deers (Rusa timorensis), and 4) enjoying the sensation and efficacy of faloak (Sterculia quadrifida) the magic skin from Flores, Sumba, Timor, and Alor island. Tourism attractions have a very important role in a tourism location since they must be presented in front of tourists, so the presenting method must be appropriate. Tourism attractions are the terminals of spatial mobility of a journey, and the conditions at the attractions must be able to hold tourists long enough (Febryano and Rusita 2018).

Accessibility from the center of Kupang City, which is close and supported by nice road facilities, although there is still about $1 \mathrm{~km}$ of roads leading to the location of the road that needs maintenance, but two or four-wheeled vehicles still can pass on it. Road maintenance needs to be done to not endanger visitors who ride motorcycles, and visitors can drive the car comfortably. Good accessibility will help visitors reach the tourism location using various transportation methods. The development of tourism objects can be conducted by increasing facilities and infrastructures, such as repairing or widening road access to the location of tourism objects (Sumarsono et al. 2020). Furthermore, improving the accessibility and infrastructure of the area around tourist attractions that is adapted to the local wisdom of the community, for example, the axis road to the location of the tourist attraction is more appropriate to make road rebates rather than paving the road (Nugroho et al. 2015). In contrast, Haris et al. (2017) stated that hard area accessibility did not cause hard accessibility. Most importantly, tourists who come with special interests do not need complete facilities but a clear path to tourism objects instead. 
KHDTK Oelsonbai is in the process of planning the spatial layout of the object area where the area planning has been included in the RPJP document, but actually, it has not been well organized. The clear status of the area as a state-organized forest and the absence of regional conflicts make it easier to do area planning in the field. People living around KHDTK Oelsonbai are local natives, most of whom are Timorese, while the rest are Sabu and Rote tribes, and there are also immigrants from Java and Sulawesi. The people around KHDTK Oelsonbai are mostly farmers, and most of them are high school graduates (BPPLHK Kupang 2020). These conditions made the potential value index of ADO ODTWA quite high. On the other hand, many communities in Nusa Tenggara Timur are experiencing socio-economic limitations (Njurumana et al. 2020). Dryland farming, which includes activities such as collecting forest products and conventional livestock farming, is the main source of income for 95\% of households (Njurumana et al. 2020).

Accommodation is a necessity which is needed by people who are making tourism trips. KHDTK Oelsonbai does not have accommodation facilities within the area, but accommodation for places to rest or stay, including hotels, inns, homestays, and others, can be easily found. Since it is located in the city of Kupang, visitors can easily find inns or hotels in the City center. The accommodation development around the site can be considered as something unique and interesting, such as homestay with traditional and nature concepts or local people's residences can be used as homestays with the concept of blending in with the community, tourists have the opportunity to learn about the existing local culture, lifestyle and industrial economy in the village (Aprilia and Rabasari 2018). According to Aswita et al. (2020), tourism potencies not only function as a place to visit in a series of tourist activities, become a source of economic income for local people and increase local revenue, but they are also placing for social interaction and cultural exchange. Also, increasing awareness of surroundings allows for deeper and stronger connections between tourists and the natural and social environment (Farkic et al. 2021).

Supporting facilities and infrastructure at KHDTK Oelsonbai match the criteria in ADO ODTWA as complete public facilities are available because the location is in Kupang City, but it requires an increase in supporting facilities in the area because they are still few. Currently, the available facilities in the area consist of work huts, greenhouses, permanent nurseries, Timor deer ex-situ conservation cages, rote snake-necked turtle ex-situ conservation enclosures, and bird exsitu conservation cages. Siswanto and Moeljadi (2015) said that good facilities and infrastructure would increase tourist visitors. Facilities improvement is very necessary and the facilities must function to serve and facilitate visitor activities carried out to get a recreational experience (Febryano and Rusita 2018). It is necessary to build supporting facilities for tourism, including building shelters or resting places for tourists while enjoying the scenery, gazebos, and Instagramable photo spots, so more tourists will be attracted. Differently, according to Haris et al. (2017), facilities and infrastructure which supported tourism activities were facilities that caused travel activities to run as expected. However, tourists with special interests surely, will not consider facilities and infrastructure as the problem.

The availability of clean water in KHDTK Oelsonbai is still low, but it is suitable for consumption with simple treatment. Generally, the Nusa Tenggara Timur region has a dominant dry climate because the rainy season lasts for 5 months (November-March) and the dry season lasts for 7 months (April-October) (Kaho et al. 2019). Based on this, the water continuity is only available for about 6-9 months. The water is available in sufficient water volume. With a spring distance of less than $1 \mathrm{~km}$, it is easy to flow it to the object. According to Dwijayani and Hadi (2013), water availability is important in life, not only in the household sector but also in the 
tourism and industrial sectors. In tourism activities, clean water is needed to support management facilities and tourism services.

\subsection{Scientific Tourism Development Strategies of Oelsonbai Research Center at KHDTK Oelsonbai using SWOT Analysis}

The determination of development strategies was carried out using SWOT analysis with an internal factor strategy analysis and an external factor strategy analysis (Latupapua et al. 2019). Based on internal and external factors identification, questionnaires (internal and external factors) were then distributed to 2 respondents from BPPLHK Kupang researchers to be weighed on each variable. Respondents would determine weights based on the contribution of the influence of these strengths or weaknesses on the achievement of the Oelsonbai Research Center scientific tourism development. The greater the weight, the higher the contribution/influence to the achievement of the Oelsonbai Research Center scientific tourism development will be. Respondents determined branches by assessing the position of each factor with the amount of capital owned by KHDTK Oelsonbai. The internal and external environment analysis can be seen in Table 2 and Table 3.

Table 2. Internal environment analysis

\begin{tabular}{|c|c|c|c|}
\hline Strength (S) & Total & Weakness (W) & Total \\
\hline The area status confirmation & 0.24 & Inadequate supporting facilities & 0.18 \\
\hline $\begin{array}{l}\text { Uniqueness and the attraction of the } \\
\text { tourism object }\end{array}$ & 0.21 & $\begin{array}{l}\text { Inadequate information and promotion } \\
\text { about Oelsonbai Research Center }\end{array}$ & 0.21 \\
\hline $\begin{array}{l}\text { Meets adequate ADO ODTWA } \\
\text { potentials to be developed as a natural } \\
\text { tourism }\end{array}$ & 0.21 & $\begin{array}{l}\text { The inadequacy of the streets, roads, and } \\
\text { good highways to the Oelsonbai }\end{array}$ & 0.08 \\
\hline $\begin{array}{l}\text { Has adequate planning to be a scientific } \\
\text { tourism attraction }\end{array}$ & 0.15 & $\begin{array}{l}\text { Insufficient capital to develop the } \\
\text { tourism attraction }\end{array}$ & 0.08 \\
\hline $\begin{array}{l}\text { Has sufficient documents like RPJP } \\
\text { (Long-Term Development Planning) }\end{array}$ & 0.17 & $\begin{array}{l}\text { The inadequacy of human resources as } \\
\text { the administrators of the scientific } \\
\text { tourism }\end{array}$ & 0.10 \\
\hline $\begin{array}{l}\text { Sufficient infrastructure as the first steps } \\
\text { towards development }\end{array}$ & 0.12 & $\begin{array}{l}\text { Lack of partnership programs in } \\
\text { managing KHDTK Oelsonbai }\end{array}$ & 0.12 \\
\hline $\begin{array}{l}\text { The level of the hospitality of the } \\
\text { administrators/managers of the KHDTK }\end{array}$ & 0.18 & $\begin{array}{l}\text { Insufficiency of the planning documents } \\
\text { of the scientific tourism }\end{array}$ & 0.08 \\
\hline Sufficient professional researchers & 0.06 & $\begin{array}{l}\text { Identification and connection } \\
\text { insufficiency of the tourist attraction } \\
\text { potentials }\end{array}$ & 0.21 \\
\hline $\begin{array}{l}\text { Sufficient data of the potentials of the } \\
\text { tourism attraction }\end{array}$ & 0.08 & $\begin{array}{l}\text { BPPLHK Kupang has not been focusing } \\
\text { on the development of the Oelsonbai } \\
\text { Research Center }\end{array}$ & 0.08 \\
\hline $\begin{array}{l}\text { The map of the tourist attraction had } \\
\text { already been made }\end{array}$ & 0.10 & $\begin{array}{l}\text { The planning concept had not been } \\
\text { executed well }\end{array}$ & 0.01 \\
\hline Total & 1.52 & Total & 1.15 \\
\hline
\end{tabular}


Table 3. External environment analysis

\begin{tabular}{|c|c|c|c|}
\hline Opportunities (O) & Total & Threats (T) & Total \\
\hline $\begin{array}{l}\text { Accessibility from the nearest town, } \\
\text { Kupang }\end{array}$ & 0.48 & $\begin{array}{l}\text { Unstable financial/economy and people } \\
\text { low income }\end{array}$ & 0.33 \\
\hline $\begin{array}{l}\text { The destination for the education and } \\
\text { research for the high education institution } \\
\text { like universities or institutes outside } \\
\text { BPPLHK Kupang }\end{array}$ & 0.48 & The decrease of tourism level & 0.18 \\
\hline Tourism destination for students & 0.33 & Online school system & 0.27 \\
\hline The ever-developing digital media & 0.17 & Other more attractive tourism attraction & 0.27 \\
\hline $\begin{array}{l}\text { The supports of every institution and } \\
\text { public in developing the tourist attraction }\end{array}$ & 0.22 & Trash and vandalism & 0.27 \\
\hline Total & 1.68 & Total & 1.32 \\
\hline
\end{tabular}

Based on the analysis results of the internal environment, the difference between the total values of strengths and weaknesses was positive 0.37 . It indicated that the strength factor is greater than the weakness factor. In the external environment analysis, the difference between the total value of opportunities and the value of threats is positive, which is 0.36 . Therefore, it showed that the opportunity factor is greater than the threat factor. Based on these two values, it can be seen that the strategy for developing scientific tourism through Oelsonbai Research Center at KHDTK Oelsonbai is currently in quadrant 1 (one), namely the SO strategy as shown in Fig. 6. The four types of strategies are shown in Table 4.

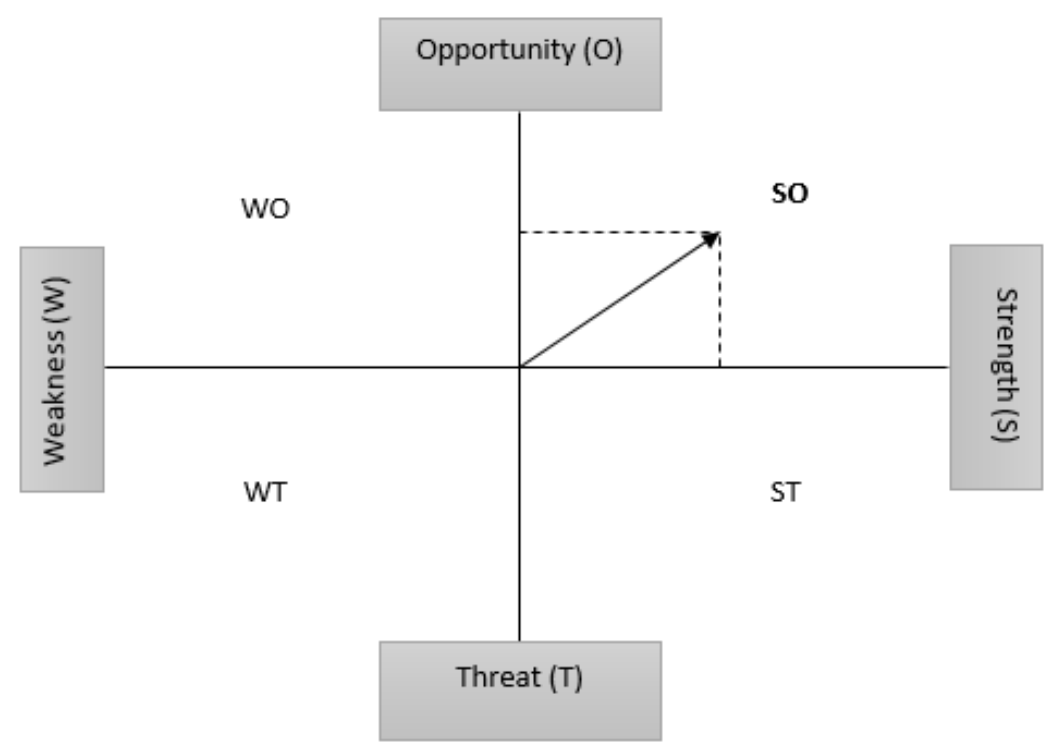

Fig. 6. Cartesian diagram of SWOT analysis. 
Table 4. SWOT Matrix

\begin{tabular}{|c|c|c|}
\hline External factors & $\begin{array}{l}\text { Strengths (S) } \\
\text { - The area status confirmation } \\
\text { - Tourism uniqueness and attraction } \\
\text { - Has adequate ADO ODTWA } \\
\text { potentials to be developed natural } \\
\text { tourism } \\
\text { - Has adequate planning as a scientific } \\
\text { tourism attraction } \\
\text { - Has RPJP document for KHDTK } \\
\text { management } \\
\text { - There are facilities and infrastructures } \\
\text { as the first step of the development } \\
\text { process } \\
\text { - The hospitality of KHDTK } \\
\text { management } \\
\text { - It has sufficient researchers. } \\
\text { - Area potentials data is provided } \\
\text { - The map of the area's planning had } \\
\text { been made }\end{array}$ & $\begin{array}{l}\text { Weaknesses (W) } \\
\text { - Lack of supporting facilities } \\
\text { - Inadequate information and } \\
\text { promotion of the Oelsonbai Research } \\
\text { Center } \\
\text { - Inadequate roads and streets in the } \\
\text { area } \\
\text { - Insufficient capital to develop the } \\
\text { tourism object } \\
\text { - Insufficient human resources in } \\
\text { scientific tourism } \\
\text { - Management partnership has not } \\
\text { been established } \\
\text { - No planning document of the } \\
\text { Oelsonbai Research Center research } \\
\text { tourism } \\
\text { - The potentials of supporting tourism } \\
\text { attraction have not been identified } \\
\text { and well connected } \\
\text { - BPPLHK Kupang has not been } \\
\text { focusing on Oelsonbai Research } \\
\text { Center development } \\
\text { - The concept of planning has not been } \\
\text { made }\end{array}$ \\
\hline $\begin{array}{l}\text { Opportunities (O) } \\
\text { - The site is near Kupang and } \\
\text { has access to highway } \\
\text { - Has the ability to be an } \\
\text { educational and research } \\
\text { object for both the domestic } \\
\text { and foreign university students } \\
\text { and researchers and to be the } \\
\text { students' tourism destination } \\
\text { - The ever-developing digital } \\
\text { media } \\
\text { - The supports of other parties } \\
\text { in tourism development } \\
\text { - New job opportunities for } \\
\text { local residents }\end{array}$ & $\begin{array}{l}\text { SO Strategy } \\
\text { - Developing the potentials of the area } \\
\text { by increasing the quality of the } \\
\text { tourist attraction } \\
\text { - The careful planning of the forest } \\
\text { area had been made, and the potential } \\
\text { of scientific tourism has been } \\
\text { identified } \\
\text { - Increasing the socialization and } \\
\text { promotion with digital media } \\
\text { - The increase of cooperation relation } \\
\text { between professional researchers } \\
\text { with other researchers and } \\
\text { educational academics } \\
\text { - The involvement of local residents in } \\
\text { tourism by establishing workforce } \\
\text { alliance, just like a cooperative } \\
\text { - The cooperation steps to start with } \\
\text { other parties in developing the } \\
\text { Oelsonbai Research Center scientific } \\
\text { tourism }\end{array}$ & $\begin{array}{l}\text { WO Strategy } \\
\text { - Documenting the planning of the } \\
\text { Oelsonbai Research Center scientific } \\
\text { tourism } \\
\text { - Establishing management body of } \\
\text { the Oelsonbai Research Center } \\
\text { scientific tourism } \\
\text { - Increasing the socialization and } \\
\text { promotion through digital media } \\
\text { - Increasing the involvement of the } \\
\text { local residents by establishing small } \\
\text { enterprises like a cooperative } \\
\text { - Establishing cooperation with other } \\
\text { parties in developing the Oelsonbai } \\
\text { Research Center scientific tourism }\end{array}$ \\
\hline $\begin{array}{l}\text { Threats }(\mathbf{T}) \\
\text { - The unstable economy and } \\
\text { low purchasing power of } \\
\text { people } \\
\text { - Discouraged tourism } \\
\text { - The online school learning } \\
\text { system } \\
\text { - Other more attractive tourism } \\
\text { objects } \\
\text { - Littering and vandalism }\end{array}$ & $\begin{array}{l}\text { ST Strategy } \\
\text { - Developing potentials of the tourism } \\
\text { site with better quality to compete } \\
\text { with other tourism attractions } \\
\text { - Transforming information and } \\
\text { socialization through digital media }\end{array}$ & $\begin{array}{l}\text { WT Strategy } \\
\text { - Well-planned management of the } \\
\text { Oelsonbai Research Center } \\
\text { scientific tourism } \\
\text { - Transforming socialization and } \\
\text { promotion through digital media }\end{array}$ \\
\hline
\end{tabular}


The Oelsonbai Research Center's scientific tourism development strategies, which are based on the SWOT matrix, suggested 6 strategies. By developing the potential of the area with better quality tourism objects, it is expected to attract more visitors. The area planning which has been stated in the RPJP will be executed immediately along with its scientific tourism attractions, namely several plans for the theme of tourism attractions which will be offered by the Oelsonbai Research Center scientific tour at KHDTK Oelsonbai, namely 1) exploring sandalwood (Santalum album) life, 2) admiring the exotic rote snake-necked turtle (Chelodina mccordi), one of the endemic animals of Nusa Tenggara Timur, 3) spending time with Javan deers (Rusa timorensis) and 4) enjoying the sensation and efficacy of faloak (Sterculia quadrifida), the magic skin from flobamora. Such as in KHDTK Aek Nauli, which provides opportunities for visitors to get to know and learn Sumatran elephants and at the same time get to know the science and technology information center at KHDTK Aek Nauli (bee gallery, captivity deer, arboretum, flora and fauna in KHDTK Aek Nauli) in a scientific package (Situmorang et al. 2020).

Increasing socialization and promotion activities using digital media is important. According to Leunga et al. (2013), promoting through social media has a significant impact on consumers and tourism service providers. It helps tourists in tourism planning and helps tourism providers compete for promotion, distribution, and management. Pramana et al. (2019) stated that Instagram is the most frequently used social media, especially for students. Increasing the collaborative relationship between researchers at BPPLHK Kupang with other researchers and academics in educational, research, and scientific tourism activities is one of the efforts to promote Oelsonbai Research Center's scientific tourism to researchers and academics. Local society is involved in tourism activities by forming business institutions like cooperatives. According to Nugroho et al. (2016), society shows a positive response through the benefits obtained from social and economic aspects and the environment. High society participation shows their ability to respond to tourist needs by providing good services while viewing tourism as an opportunity to gain economic benefits (Kaharuddin et al. 2020). Nugroho et al. (2021) stated that partnerships in managing tourism destinations have primarily strengthened the local's role in managing forest areas. Establishing cooperation with other parties in developing Oelsonbai Research Center scientific tourism may help to solve limited capital for the development of Oelsonbai Research Center scientific tourism. Subarudi et al. (2020) stated that given the wide scope of work to develop scientific tourism and limited resources, collaboration with various stakeholders is very important.

The development of Oelsonbai Research Center scientific tourism has the potential to get more visitors considering its strategic location in Kupang City, so it can be an alternative transit tourism destination for airlines passengers arriving at and departing from the same airport on the same day (Poon and Ho 2021) especially tourists whom to go to Komodo National park. As we know, Komodo National Park is already well known to foreign countries and as a member of seven wonders in 2012 (Lasso and Dahles 2017; Hidyarko et al. 2021). Transit tourism is an opportunity (Poon and Ho 2021). The existence of the Oelsonbai Research Center scientific tourism location is also very beneficial in reaching the market target to find millennials, students, and university students. According to the research results of Taye et al. (2019), forest tourism for students is very important because it is beneficial for a healthy lifestyle and health investment for the future. Unique tourism attractions like endemic flora and fauna and other interesting educational tour packages and environmental conditions with natural scenery and shady forests become high. If Oelsonbai Research Center scientific tourism at BPPLHK Kupang is managed properly, these conditions will attract more visitors. It is important to revisit various technicalities management 
strategies (Azizah 2017) and consider suggestions from various parties to improve the better management of the Oelsonbai Research Center. Research results can help analyze tourism problems and determine potential improvement actions (Reihanian et al. 2012).

\section{Conclusions}

The result of the research indicated that the Oelsonbai Research center had the potentials and to be developed into a tourism area. The potential evaluation for ADO ODTWA KHDTK Oelsonbai reached $82.81 \%$, indicating its potential and properness to be developed as a tourism area. The proposed strategies for the development of Oelsonbai Research Center scientific tourism are: developing the potential of the area with better quality tourism objects, executing the created forest area and scientific tourism attraction planning, increasing socialization and promotion activities with digital media, increasing collaborative relations between researchers and other researchers and academics in education, research and scientific tourism, involving the community in tourism activities by establishing business institutions such as cooperatives and establishing cooperation with other parties in developing the Oelsonbai Research Center scientific tourism. A breakthrough from the management is needed to improve management, especially improving the quality of location accessibility, the level of cleanliness, the ease of getting information from the media, facilities, and infrastructure, as well as transportation and the level of visitor comfort so that it is in accordance with other variables in the good category. Improvements to these aspects will have implications for increasing the value of the potential properness of ADO ODTWA KHDTK Oelsonbai. Properness value increase needs to be followed by management performance improvement of Oelsonbai Research Center in KHDTK Oelsonbai, creating a special division that focuses on improving services and providing supporting facilities and infrastructure.

\section{Acknowledgments}

The main first author would like to express sincere gratitude for Latsar CPNS KLHK 2021 program. The manuscript was made because of that program. In addition, we thank the respondents who share valuable information during the data collection. Also, we would like to express sincere gratitude to anonymous reviewers for their constructive contribution to improving the manuscript.

\section{References}

Affandy, B., Setiawan, A., and Duryat. 2016. Potensi Wisata Alam di Pematang Tanggang Desa Negeri Kecamatan Kelumbayan Kabupaten Tanggamus. Jurnal Sylva Lestari 4(1): 41-50. DOI: $10.23960 /$ jsl1441-50

Alwi, A. 2015. Kriteria Empirik dalam Menentukan Ukuran Sampel pada Pengujian Hipotesis Statistika dan Analisis Butir. Jurnal Formatif 2(2): 140-148. DOI: 10.30998/formatif.v2i2.95

Aprilia, L. R., and Rabasari, S. 2018. Community Perception and Participation in Preserving Lebak Muncang Tourism Village (Through Alteration of Local Resident's Homes Become a Homestay). 1st International Conference One Belt, One Road, One Tourism (ICOBOROT 2018). Advances in Economics, Business and Management Research 3: 44-49. DOI: 10.2991/icoborot-18.2019.7 
Aswita, D., Suryadarma, I. G. P., Suyanto, S., and Herawan, T. 2020. The Natural Resources Potency of Marine Ecotourism as an Environmental Education Source. Geojournal of Tourism and Geosites 31(3): 996-1003. DOI: 10.30892/gtg.31310-533

Azizah, A. 2017. Tourism Development and Strategy for Increasing Numbers of Visitors in Kediri. Journal of Indonesian Tourism and Development Studies 5(2): 131-136. DOI: 10.21776/ub.jitode.2017.005.02.09

Bangsawan, I., Wibowo L. R., Subarudi, Hudiyani, I., Hakim, L., Kurniasari D. R., and Mulyadin, L. M. 2021. Model of Conflict Resolution at KHDTK Carita Through Participatory Action Research. INAFOR 2021 Stream 4. IOP Conf. Series: Earth and Environmental Science 917. DOI: $10.1088 / 1755-1315 / 917 / 1 / 012008$

Barus, J. A., Hidayat, J., W., and Maryono. 2018. Primates (Symphalangus syndactylus, Macaca nemestrina, Macaca fascicularis) Population in the Ape Park Tourist Area Forest for Special Purpose of Aek Nauli. E3S Web of Conferences 73(2). DOI: 10.1051/e3sconf/20187304018 Bhuiyan, M. A. H., Siwar, C., and Islam, R. 2010. Ecotourism and Environmental Education: An Opportunity for Bangladesh. Proc. of International Conference on Environmental Aspects of Bangladesh (ICEAB10) 43-44.

Bos, L., McCabe, J., and Johnson, S. 2015. Learning Never Goes on Holiday: An Exploration of Social Tourism as a Context for Experiential Learning. Current Issue in Tourism (18)9: 859875. DOI: $10.1080 / 13683500.2013 .790878$

BPPLHK Kupang. 2020. Rencana Pengelolaan Jangka Panjang (RPJP) KHDTK Litbang Kehutanan Oelsonbai Tahun 2020-2039. Balai Penelitian dan Pengembangan Lingkungan Hidup dan Kehutanan Kupang (BPPLHK Kupang), Kupang, Indonesia.

Cahyadi, H. S., and Newsome, D. 2021. The Post COVID-19 Tourism Dilemma for Geoparks In Indonesia. International Journal of Geoheritage and Parks 9(2): 199-211. DOI: 10.1016/j.ijgeop.2021.02.003

Chen, F., Liu, J., Wu, J., Sjafrie N. D. M., Rahmadi, P., and Putranto, R. Y. 2021. Measuring the Relationship Among Stakeholders from Value-Satisfaction-Demand in the Development of Ecotourism of Marine Park. Marine Policy 129. DOI: 10.1016/j.marpol.2021.104519

Dewi, D., Darwo, Yeni, I., Andadari, L., and Bogidarmanti. 2021. Agroforestry Development in Lake Toba Catchment Area: farmer's Perception and Interest. INAFOR 2021 Stream 2. IOP Conf. Series: Earth and Environmental Science 914. DOI: 10.1088/1755$1315 / 914 / 1 / 012038$

Dinhopl, A., and Gretzel, U. 2016. Selfie-Taking as Touristic Looking. Annals of Touristic Research 57: 126-139. DOI: 10.1016/j.annals.2015.12.015

Dirjen PHKA. 2003. Pedoman Analisis Daerah Operasi Obyek dan Daya Tarik Wisata Alam. Direktorat Wisata Alam dan Pemanfaatan Jasa Lingkungan (Dirjen PHKA), Bogor, Indonesia.

Dwijayani, A. A. P., and Hadi, W. 2013. Studi Kelayakan Pengolahan Air Laut menjadi Air Bersih di Kawasan Wisata dan Pelabuhan Perikanan Nusantara (PPN) Pantai Prigi, Trenggalek. Jurnal Teknik ITS 2(2). DOI: 10.12962/j23373539.v2i2.4132

Farkic, J. Isailovic, G., and Taylor S. 2021. Forest Bathing as a Mindful Tourism Practice. Annals of Tourism Research Empirical Insights 2(2). DOI: 10.1016/j.annale.2021.100028

Febryano, I. G., and Rusita. 2018. Persepsi Wisatawan dalam Pengembangan Wisata Pendidikan Berbasis Konservasi Gajah Sumatera (Elephas maximus sumatranus). Jurnal Pengelolaan Sumberdaya Alam dan Lingkungan 8(3): 376-382. DOI: 10.29244/jps1.8.3.376-382 
Fitroh, R., Oktavia, W. K., and Hanifah, H. 2019. Perbedaan Perilaku Prososial Ditinjau dari Jenis Kelamin pad Relawan Sosial. Jurnal Psikologi Terapan dan Pendidikan 1(1): 9-15. DOI: 10.26555/jptp.v1i1.15125

Gay, L. R., Mills, G. E., and Airasian, P. W. 2012. Educational Research, Competencies for Analysis And Applications. New Jersey: Pearson Education, Inc.

Haris, M., Soekmadi, R., and Arifin, H. S. 2017. Potensi Daya Tarik Ekowisata Suaka Margasatwa Bukit Batu Kabupaten Bengkalis Provinsi Riau. Jurnal Penelitian Sosial dan Ekonomi Kehutanan 14(1): 39-56. DOI: 10.20886/jsek.2017.14.1.39-56

Hernandez, J. M., Jimenez, Y. S., and Martel, C. G. 2021. Factors Influencing the Co-Occurrence of Visits Co-Attractions: The Case of Madrid, Spain. Tourism Management 83(6). DOI: 10.1016/j.tourman.2020.104236

Hidayat, O. 2016. Keragaman Spesies Avifauna Hutan Penelitian Oilsonbai-Kupang NTT. Prosiding Seminar Hasil Litbang. Peran IPTEK Hasil Hutan Bukan Kayu untuk Kesejahteraan Masyarakat Nusa Tenggara Timur. Pusat Penelitian dan Pengembangan Konservasi dan Rehabilitasi Badan Litbang dan Inovasi, Bogor, Indonesia.

Hidyarko, A. I. F., Gayatri, A. C., Rifa, V. A., Astuti, A., Kusumaningrum, L. Mau, Y. S., Rudiharto, H., and Setyawan, A. D. 2021. Review: Komodo National Park as a Conservation Area for the Komodo Species (Varanus komodoensis) and Sustainable Tourism. International Journal of Tropical Drylands 5(1): 27-41. DOI: 10.13057/tropdrylands/t050105

Hutapea, F. J., Kuswanda, W., and Barus, S. P.2021. Productivity and Feed Management Strategies of Sambar Deer (Rusa unicolor) at the Special Purpose Forest area (KHDTK) of Aek Nauli. The 2nd International Conference on Natural Resources and Technology. IOP Conf. Series: Earth and Environmental Science 713(1). DOI: 10.1088/17551315/713/1/012007

Jangra, R., Kaushik, S. P., and Saini, S. S. 2021. An Analysis of Tourist's Perceptions Toward Tourism Development: Study of Cold Desert Destination, India. Geography and Sustainability 2(1): 48-58. DOI: 10.1016/j.geosus.2021.02.004

Kaho, N. P. L. B. R, and Mau, A. E. 2019. Draft Rencana Pengelolaan Hutan Penelitian Oelsonbai. Pusat Unggulan IPTEK Lahan Kering Kepulauan Universitas Nusa Cendana dan Balai Peneltian dan Pengembangan Lingkungan Hidup dan Kehutanan Kupang. Kupang, Indonesia.

Kahruddin, Pudyatmoko, S., Fandeli, C., and Martani, W. 2020. Partisipasi Masyarakat Lokal dalam Pengembangan Ekowisata. Jurnal Ilmu Kehutanan 14(1): 42-54. DOI: 10.22146/jik.57462

Karsudi, Soekmadi, R., and Kartodihardjo, H. 2010. Strategi Pengembangan Ekowisata di Kabupaten Kepulauan Yapen Provinsi Papua. Jurnal Manajemen Hutan Tropika 15(3): 148154. DOI: $10.7226 / \mathrm{jtfm} .16 .3 . \% 25 \mathrm{p}$

Konu, H. 2015. Developing a Forest-Based Wellbeing Tourism Product Together with CustomersAn Ethnographic Approach. Tourism Management 49: 1-16. DOI: 10.1016/j.tourman.2015.02.006

Lasso, A., and Dahles, H. 2018. Are Tourism Livelihoods Sustainable? Tourism Development and Economic Transformation on Komodo Island, Indonesia. Asia Pacific Journal of Tourism Research 23(5): 473-485. DOI: 10.1080/10941665.2018.1467939 
Latupapua, Y. T., Loppies, R., and Fara, F. D. S. 2019. Analisis Kesesuaian Kawasan Mangrove sebagai Objek Daya Tarik Ekowisata di Desa Siahoni, Kabupaten Buru Utara Timur, Provinsi Maluku. Jurnal Sylva Lestari 7(3): 267-276. DOI: 10.23960/js137267-276

Leunga, D., Lawa, R., van Hoofb, H., and Buhalisc, D. 2013. Social Media in Tourism and Hospitality: a Literature Review. Journal of Travel and Tourism Marketing 30(102): 3-22. DOI: $10.1080 / 10548408.2013 .750919$

Li, T. T., Liu, F., and Soutar, G. N. 2021. Experiences, Post-Trip Destination Image, Satisfaction, and Loyalty: A Study in an Ecotourism Context. Journal of Destination Marketing and Management 19(1). DOI: 10.1016/j.jdmm.2020.100547

Maskulino, and Panjaitan, S. 2020. Kajian Pengelolaan Berkelanjutan KHDTK Aek Nauli dalam Mendukung Upaya Konservasi Lingkungan di Kawasan Danau Toba, Sumatera Utara. Prosiding Seminar Nasional Lingkungan Lahan Basah 5(3): 79-84.

Meizannur, and Wulandari, C. 2015. Analisis Pengembangan Obyek Wisata Alam di Resort Balik Bukit Taman Nasional Bukit Barisan Selatan. Jurnal Sylva Lestari 3(1): 51-62. DOI: 10.23960/js11351-62

Messakh, J. J., Moy, D. L., Mojo, D., and Maliti, Y. 2017. The Linkage Between Household Water Consumption and Rainfall in the Semi-Arid Region of East Nusa Tenggara, Indonesia. The 4th International Seminar on Sustainable Urban Development. IOP Conf. Series: Erath and Environmental Science 106(1). DOI: 10.1088/1755-1315/106/1/012084

MCI RI (Ministry of Communication and Information, Republic of Indonesia). 2017. Survey Penggunaan TIK Serta Implikasinya terhadap Aspek Sosial Budaya Masyarakat. Kementerian Komunikasi dan Informatika. Jakarta, Indonesia.

MoEF RI (Ministry of Environment and Forestry, Republic of Indonesia). 2020. Rencana Strategis Tahun 2020-2024. Kementerian Lingkungan Hidup dan Kehutanan. Jakarta, Indonesia.

MoF RI (Ministry of Forestry, Republic of Indonesia). 2003. Pedoman Analisis Daerah Operasi Obyek dan Daya Tarik Wisata Alam. Kementerian Kehutanan. Jakarta, Indonesia.

Njurumana, G. N., Ginoga, K. L., and Octavia, D. 2020. Sustaining Farmers Livelihoods Through Community Forestry in Sikka, East Nusa Tenggara, Indonesia. Biodiversitas 21(8). 37863796. DOI: $10.13057 /$ biodiv/d210846

Nugroho, A. F., Ichwandi, I., and Kosmaryandi, N. 2017. Analisis Pengelolaan Kawasan Hutan Dengan Tujuan Khusus (Studi Kasus Hutan Pendidikan dan Latihan Gunung Walat). Journal of Env. Engineering and Waste Management 2(2): 51-59.

Nugroho, J. W., Gandasasmita, W., and Manuwoto. 2015. Arahan Pengembangan Obyek Wisata Menuju Pembangunan Pariwisata Berkelanjutan di Kabupaten Wonogiri. Kawistara 5(3): 221-328. DOI: 10.22146/kawistara. 10053

Nugroho, I., Pramukanto, F. H., Negara, P. D., Purnomowati, W., and Wulandari, W. 2016. Promoting the Rural Development through the Ecotourism Activities in Indonesia. American Journal of Tourism Management 5(1): 9-18. DOI: 10.5923/j.tourism.20160501.02

Nugroho, P., Wiyono, and Alhafi, A. N. 2021. Delivering Benefits from State Forest: Lesson from Partnership of Nature-Based Tourism Development in KPH Yogyakarta. Jurnal Sylva Lestari 9(2): 239-251. DOI: 10.23960/js129239-251

Newsome, D. 2020. The Collapse of Tourism and Its Impact on Wildlife Tourism Destinations. Journal of Tourism Futures 7(3). DOI: 10.1108/jtf-04-2020-0053 
Pezenka, I., and Wiesmayer, C. 2020. Which Factors Influence Locals' and Visitors' Overall Restaurant Evaluations?. International Journal of Contemporary Hospitality Management 32(9). DOI: 10.1108/ijchm-09-2019-0796

Poon, P. C. M., and Ho, G. K. S. 2021. Opportunities in Transit Tourism: a Case Study of Hong Kong as a Transit Destination. Journal of Travel and Tourism Marketing 38(1): 31-43. DOI: $10.1080 / 10548408.2020 .1862024$

Rafii, A. M., Restu, M., Millang, S., and Muin, M. 2020. Analysis of Programs of Activities Development of Forest Areas with Specific Objectives (KHDTK) Tabo-Tabo South Sulawesi. IC-FSSAT. IOP Conf. Series: Earth and Environmental Science 486(1). DOI: $10.1088 / 1755-1315 / 486 / 1 / 012034$

Rahayu, A.S., Yani, A., and Malik, Y. 2015. Pemanfaatan Taman Wisata Alam Situ Gunung sebagai Sumber Belajar Geografi SMA di Kabupaten Sukabumi. Antologi Geografi 3(2): 19.

Rahmawati, P. I., Trianasari, and Suarmanayasa. 2021. Feasibility of Developing Butterfly Park as Educational Tourism in Wonogiri Village Forest in Bali. 6th International Conference on Tourism, Economics, Accounting, Management, and Social Science (TEAMS 2021). Advances in Economics, Business, and Management Research 197. DOI: 10.2991/aebmr.k.211124.004

Pramana, I. I. A. W., Leksono, A. S., and Djati, M. S. 2019. Strategies to Introducing Ecotourism Concept with Social Media for College Student in Malang. Journal of Indonesian Tourism and Development Studies 7(2). DOI: 10.21776/ub.jitode.2019.07.02.01

Purwanto, S., Syaufina, L., and Gunawan, A. 2014. Kajian Potensi dan Daya Dukung Taman Wisata Alam Bukit Kelam untuk Strategi Pengembangan Ekowisata. Jurnal Pengelolaan Sumberdaya Alam dan lingkungan 4(2): 119-125. DOI: 10.29244/jpsl.4.2.119

Reihanian, A., Mahmood, N. Z. B., Kahrom, E., and Hin, T. W. 2012. Sustainable Tourism Development Strategy by SWOT Analysis: Boujagh National Park, Iran. Tourism Management Perspective 4: 223-228. DOI: 10.1016/j.tmp.2012.08.005

Saputra, S. E., and Setiawan, A. 2014. Potensi Ekowisata Hutan Mangrove di Desa Merak Belantung Kecamatan Kalianda Kabupaten Lampung Selatan. Jurnal Sylva Lestari 2(2): 4960. DOI: $10.23960 /$ js12249-60

Setiyono, B., Sarwono, and Hermawan. 2012. Perencanaan Pengembangan Wisata Alam dan Pendidikan Lingkungan di Kawasan Hutan dengan Tujuan khusus (KHDTK) Cikampek. Wacana 15(3): 62-69.

Sihite, R. Y., Setiawan A., and Dewi, B. S., 2018. Potensi Obyek Wisata Alam Prioritas di Wilayah Kerja KPH Unit XIII Gunung Rajabasa, Way Pisang, Batu Serampok, Provinsi Lampung. Jurnal Sylva Lestari 6 (2): 84-93. DOI: 10.23960/js12684-93

Silvano, A. P., Eriksson, J., and Henriksson, P.2020. Company Respondent Characteristics Based on Different Travel Survey Data Collection and Respondent Recruitment Methods. Case Studies on Transport Policy 8(3): 870-877. DOI: 10.1016/j.cstp.2020.05.015

Siswanto, A., and Moeljadi. 2015. Eco-tourism Development Strategy Baluran National Park in the regency of Situbondo, East Java, Indonesia. Journal of Evaluation and Research in Education 4(4): 185-195. DOI: 10.11591/ijere.v4i4.4510

Situmorang, R. O. P., Silalahi, J., and Kuswanda, W. 2020. Persepsi Stakeholder pada Pengembangan Pusat Konservasi Gajah di KHDTK Aek Nauli. Jurnal Penelitian Sosial dan Ekonomi Kehutanan 17(2): 83-100. DOI: 10.33626/inovasi.v16i2.150 
Sjodin, C., and Kritensson, P. 2013 Customer's Experiences of Co-Creation during Service Innovation. International Journal of Quality and Service Sciences 4(2): 189-204. DOI: $10.1108 / 17566691211232918$

Subarudi, Herawati T., Lestari, N. S., Surati, and Rohadi, D. 2020. Pengembangan Model Kolaborasi Eko-eduwisata: Pembelajaran dari KHDTK Aek Nauli. Policy Brief. Pusat Penelitian dan Pengembangan Sosial, Ekonomi, Kebijakan dan Perubahan Iklim, Badan Penelitian, Pengembangan dan Inovasi, Kementerian Lingkungan Hidup dan Kehutanan. 14(8).

Sumarsono, H., Arti, H. W., and Soesilo, Y. H. 2020. The Development Strategy of Tourism Sector in Ponorogo, Indonesia. 4th Padang International Conference on Education, Economic, Bussiness and Accounting (PCEEBA-2 2019). DOI: 10.2991/aebmr.k.200305.169

Susana, M., Kusmana, C., and Arifin, H. S. 2020. Potensi Daya Tarik Ekowisata Mangrove di Desa Karangsong Kabupaten Indramayu. Jurnal Penelitian dan Ekonomi Kehutanan 17(3): 193-208. DOI: 10.20886/jpsek.2020.17.3.193-208

Taye, F. A., Abildtrup, J., Mayer, M., Scasny, M., Strange, N., and Lundhede, T. 2019. Childhood Experience in Forest Recreation Practices: Evidence From Nine European Countries. Urban Forestry and Urban Greening 46: 126471. DOI: 10.1016/j.ufug.2019.126471

Yuni, L. P. E. K., and Yuda, I. P. 2020. The Island Biogeography of Wallacea and Krakatoa Island. in: Encyclopedia of the World's Biomes M. I. Goldstein and D. A. DellaSala, eds. Elsevier, Oxford 217-229. DOI: 10.1016/b978-0-12-409548-9.11789-0 